\title{
Editorial
}

\section{La producción académica de las ciencias sociales en Latinoamérica}

\author{
Julio César Ossa \\ Universidad de San Buenaventura Cali
}

$\overline{\text { Referencia formato APA: Ossa, J. C. (Ed.). (2014). La producción académica de las ciencias sociales en Latinoamérica. Revista Cientifica Guillermo }}$ de Ockham, 12(2), 5-8.

En los últimos años, el modelo de medición de los grupos de investigación colombianos ha sufrido una serie de transformaciones importantes, una de las cuales corresponde a la importancia que el modelo de medición nacional les ha brindado a los índices de citas internacionales, tales como Web of Science y Scopus.

Estos índices brindan una valoración de la calidad editorial y científica de las producciones con base en los cuartiles en los que se publica $\left(\mathrm{Q}_{1}\right.$ supone un mayor rigor en la evaluación de los artículos que $Q_{2}$ y así sucesivamente). Los índices también ofrecen indicadores que dan cuenta de la influencia de la producción a nivel global por medio del factor de impacto (número de citas recibidas/periodo de tiempo dado).

El modelo de medición de grupos de investigación científica, desarrollo tecnológico e innovación de Colciencias, ofrece gran diversidad de indicadores que registran la producción académica de los grupos de investigación colombianos (Vélez-Cuartas, Gómez-Flórez, Úsuga-Ciro $\&$ Vélez-Trujillo, 2014). Sin embargo, pese a esa pluralidad "las instituciones educativas sólo valoran tres tipos de productos: libro de investigación, artículo en revista $A$-según el índice Publindex-y libro de texto" (p. 7).

Al observar en Scopus la tendencia de las publicaciones en ciencias sociales de los países latinoamericanos, se encuentra que la variedad de la producción se reduce ostensiblemente (Ossa, 2014). En esta base de citación, se advierte que la modalidad de publicación privilegiada son los artículos (67,1\%), seguida de los capítulos de libro $(2,9 \%)$ y los libros $(0,5 \%)$, que como se puede comprobar, tienen un porcentaje de participación bastante bajo (Figura 1).

\section{Figura 1}

Tipos de productos reconocidos por Scopus para América Latina (1995-2014)

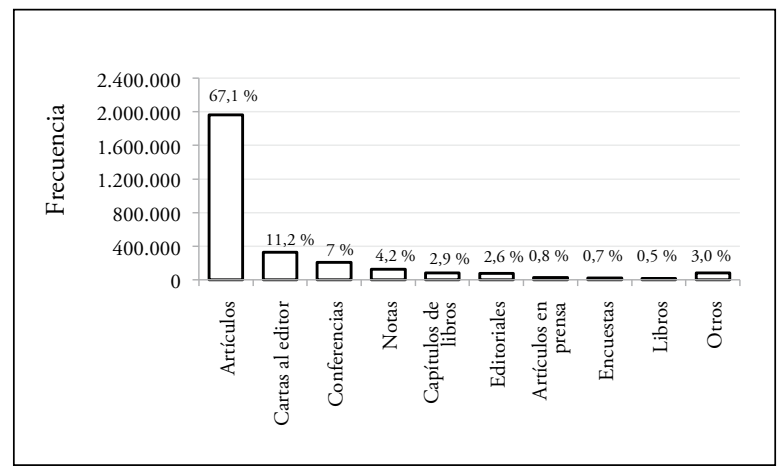

Fuente: Elaboración propia a partir de los resultados arrojados por el índice de citación Scopus (septiembre, 2014)

Es evidente que la tendencia es hacia la publicación de artículos científicos de carácter empírico (aproximadamente $58 \%$ ) y los restantes corresponden a artículos de revisión $(9,1 \%)$. Los mayores generadores de este tipo de productos son Estados Unidos (27,4 \%), Reino Unido (10,1\%), Canadá (3,5\%), Alemania $(2,8 \%)$ y China (2,6\%). Estas cinco potencias suman algo más del $53 \%$ de la producción académica de las ciencias sociales, con lo cual se verifica la estrecha relación entre los países desarrollados y su capacidad para gestionar "la visibilidad de las revistas académicas y sus productos de investigación [...] en red mundial" (Romero-Torres, Acosta-Moreno, Tejada-Gómez, 2013, p. 2).

Por su parte, la producción en América Latina de las ciencias sociales solo representa el $1,5 \%$, porcentaje que refleja la manera como la producción académica se invisibiliza en este índice de citas. Algunos de estos porcentajes son: Brasil (0,83\%); Argentina (0,19\%); Chile (0,22\%) 
y Colombia $(0,12 \%)$, entre otros. Frente a ello surge la duda: ¿cuál es la apuesta de los Estados latinoamericanos para apoyar la visibilidad de las revistas académicas y sus productos de investigación? En el caso de Colombia, sobre la base de la diversidad de productos del modelo conceptual de medición de grupos y con la intención de pensar otros criterios de medición que completen el panorama a fin de evitar el riesgo de apostar a un único factor de medición, ¿cuáles serían los criterios propios para determinar la calidad de las publicaciones nacionales?

Más importante aún: ¡cuál puede ser la estrategia para apoyar el mejoramiento de la calidad científica de las revistas y las casas editoriales nacionales? La articulación entre los programas de investigación social y los canales de comunicación de alta calidad científica y editorial (y, por qué no, los nacionales) repercutiría, sin duda, en la sociedad y más aun en la comprensión de las problemáticas locales contemporáneas.

\section{Referencias}

Vélez-Cuartas, G., Gómez-Flórez, H., Úsuga-Ciro, A., \& Vélez-Trujillo, M. (2014). Diversidad y reconocimiento de la producción académica en los sistemas de evaluación de la investigación en Colombia. Revista Española de Documentación Cientifica, 37(3), 1-14. doi: http://dx.doi.org/10.3989/ redc.2014.3.1133

Romero-Torres, M., Acosta-Moreno, L. A., \& Tejada-Gómez, M. A. (2013). Ranking de revistas científicas en Latinoamérica mediante el índice $h$ : estudio de caso Colombia. Revista Española de Documentación Científica, 36(1), 1-13. doi: http://dx.doi.org/10.3989/redc.2013.1.876

Ossa, J. C. (Septiembre, 2014). Panorama de la producción de las ciencias sociales en América Latina. Trabajo presentado en Simposio Doctorado de Educación, Universidad de San Buenaventura, Cali. 


\section{Editorial}

\section{The academic production of social sciences in Latin America}

In recent years the measurement model of Colombian research groups has been transformed. One of the fundamental changes reflects the importance that the national measurement model has provided to the international citation indexes such as Web of Science and Scopus.

Citation indexes provide an assessment of the scientific and editorial quality of the productions based on quartiles in which it is published: Journal in the first quartile (Q1) represents more rigor in evaluating than the journal in the second quartile $(\mathrm{Q} 2)$. The indexes also provide indicators that reflect the impact of global production through the impact factor (number of citations received / given time period).

The measurement model of Colciencias offers a variety of indicators to account for the academic production of the Colombian research groups (Vélez-Cuartas, GómezFlórez, Úsuga-Ciro \& Vélez-Trujillo, 2014). Despite this diversity "educational institutions only value three types of products, which are: research book, journal paper (type A) and textbook" (p. 7).

It can be observed in Scopus that the trend of publications in social sciences in Latin American countries is very low (Ossa, 2014). In Scopus we find that the privileged publication pattern is articles (67.1\%); Book chapters (2.9\%), and finally t books (0.5\%) which have a fairly low percentage of participation (see Figure 1).

Figure 1

Types of products found in Scopus for Latin America (1995-2014)

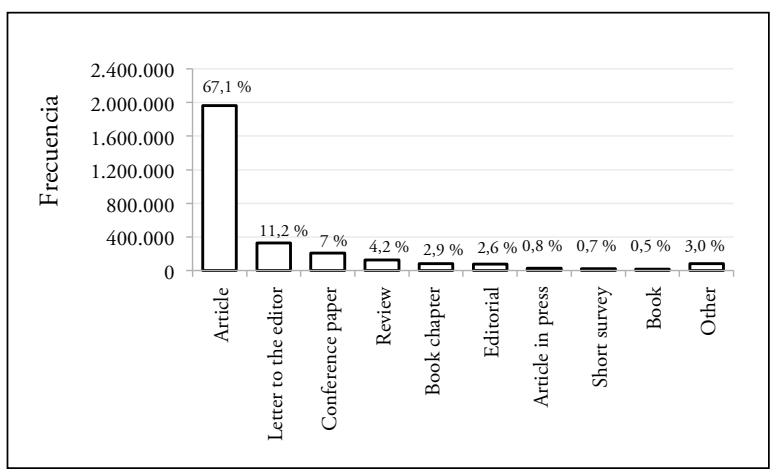

Data source: Compiled from the results obtained by the citation index Scopus (September, 2014)
Clearly, the tendency is to publish empirical scientific articles (approximately 58\%) and the remainder are review articles $(9.1 \%)$. The biggest producers of these products are the United States (27.4\%), UK (10.1\%), Canada (3.5\%), Germany $(2.8 \%)$ and China (2.6\%). These five countries account for over $53 \%$ of the academic production of social sciences; hence the close relationship between the developed countries and their ability to manage "the visibility of academic journals and research products [...] in a global network" (Romero-Torres, Acosta-Moreno, Tejada-Gómez, 2013, p. 2).

On the other hand, the production of social sciences in Latin America represents only 1.5\%. The low percentage of products of Latin American countries reflects the way the academic production seems invisible in this citation index. Some of the percentages are shown as follows: Brazil $(0.83 \%)$; Argentina $(0.19 \%)$; Chile $(0.22 \%)$; Colombia $(0.12 \%)$, among others. Because of this, the following question arises: What is the commitment of Latin American States to support the visibility of academic journals and research products? In the case of Colombia, taking into account the diversity of products of the conceptual model of group measurements, What are the criteria for determining the quality of national publications? We believe it is necessary to consider other measurement models to complete the panorama and avoid the risk of betting on a single measurement system.

More importantly is the question of what may be the strategy to support the improvement of the scientific quality of journals and national publishing houses? We believe that the link between social research programs with communication channels of high scientific and editorial quality impact on society and even more in the understanding of contemporary local issues. Therefore, we think that it is key to support national journals to improve their quality and widen their visibility worldwide.

\section{References}

Vélez-Cuartas, G., Gómez-Flórez, H., Úsuga-Ciro, A., \& Vélez-Trujillo, M. (2014). Diversidad y reconocimiento de 
la producción académica en los sistemas de evaluación de la investigación en Colombia. Revista Española de Documentación Cientifica, 37(3), 1-14. doi: http://dx.doi.org/10.3989/ redc.2014.3.1133

Romero-Torres, M., Acosta-Moreno, L. A., \& Tejada-Gómez, M. A. (2013). Ranking de revistas científicas en Latinoamérica mediante el índice $h$ : estudio de caso Colombia.
Revista Española de Documentación Cientifica, 36(1), 1-13. doi: http://dx.doi.org/10.3989/redc.2013.1.876

Ossa, J. C. (Septiembre, 2014). Panorama de la producción de las ciencias sociales en América Latina. Trabajo presentado en Simposio Doctorado de Educación, Universidad de San Buenaventura, Cali. 